\title{
MIS and SIS Solar Cells on Polycrystalline Silicon
}

Gary Cheek

Solar Energy Research Institute

Robert Mertens

E.S.A.T. Laboratory

Catholic University of Leuven, Belgium
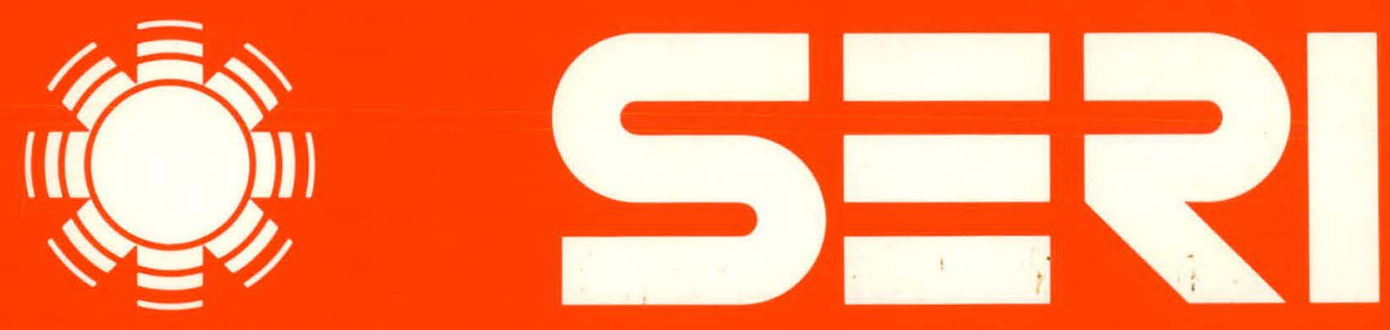

Solar Energy Research Institute

A Division of Midwest Research Institute

1617 Cole Boulevard

Golden, Colorado 80401

Operated for the

U.S. Department of Energy

under Contract No. EG-77-C-01-4042 


\section{DISCLAIMER}

This report was prepared as an account of work sponsored by an agency of the United States Government. Neither the United States Government nor any agency Thereof, nor any of their employees, makes any warranty, express or implied, or assumes any legal liability or responsibility for the accuracy, completeness, or usefulness of any information, apparatus, product, or process disclosed, or represents that its use would not infringe privately owned rights. Reference herein to any specific commercial product, process, or service by trade name, trademark, manufacturer, or otherwise does not necessarily constitute or imply its endorsement, recommendation, or favoring by the United States Government or any agency thereof. The views and opinions of authors expressed herein do not necessarily state or reflect those of the United States Government or any agency thereof. 


\section{DISCLAIMER}

Portions of this document may be illegible in electronic image products. Images are produced from the best available original document. 
Printed in the United States of America Available from:

National Technical Information Service

U.S. Department of Commerce

5285 Port Royal Road

Springfield, VA 22161

Price:

Microfiche $\$ 3.00^{5}$

Printed Copy $\$ 4.50$

\section{NOTICE}

This report was prepared as an account of work sponsored by the United States Government. Neither the United States nor the United States Department of Energy, nor any of their employees, nor any of their contractors, subcontractors, or their employees, makes any warranty, express or implied, or assumes any legal liability or responsibility for the accuracy, completeness or usefulness of any information, apparatus, product or process disclosed, or represents that its use would not infringe privately owned rights. 
SERI/TR-311-493

UC CATEGORY: UC-63

MIS AND SIS SOLAR CELLS ON POLYCRYSTALLINE SILICON

GARY CHEEK

SOLAR ENERGY RESEARCH INSTITUTE

ROBERT MERTENS

E.S.A.T. LABORATORY

CATHOLIC UNIVERSITY OF LEUVEN, BELGIUM

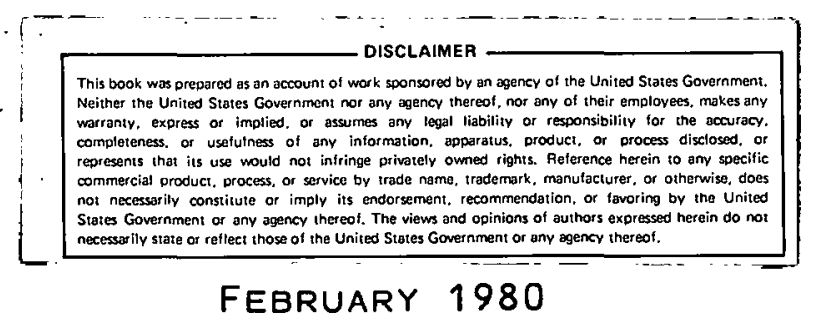

PREPARED UNDER TASK NO. 3821.02

Solar Energy Research Institute

1536 Cole Boulevard

Golden, Colorado 80401

A Division of Midwest Research Institute

Prepared for the

U.S. Department of Energy

Contract No. EG $\cdot 77 \cdot C \cdot 01 \cdot 4042$ 
THIS PAGE

\section{WAS INTENTIONALLY \\ LEFT BLANK}




\section{FOREWORD}

This document was prepared as a basis for a critical assessment of the SERI funded programs in the area of MIS/SIS solar cells. Dr. Robert P. Mertens co-authored the publication while on leave from the Katholieke Universiteit in Leuven, Belgium.

The authors would like to express their gratitude to Dr. J.R. Burke of PVPO for help in organizing the assessment program. Also, to Dr. D.L. Feucht for providing much technical support during the writing of this report.

Approved fon:

SOLAR. FNERGY RESEARCH INSTITUTE

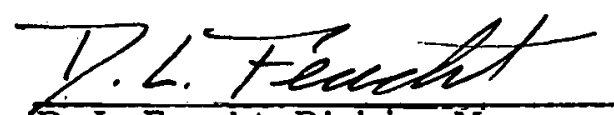

D. L. Feucht, Division Manager

Photovoltaic Advanced Silicon 


\section{THIS PAGE}

\section{WAS INTENTIONALLY \\ LEFT BLANK}




\section{SUMMARY}

Metal-Insulator-Semiconductor (MIS) and Semiconductor-Insulator-Semiconductor (SIS) structured solar cells have been considered a viable alternative to thermally diffused $p-n$ junctions for use on polycrystalline thin-film silicon substrates. Early work indicated that thermal diffusion of a junction in polycrystalline silicon substrates could impose severe problems. Experimental investigations have shown that a $\mathrm{p}-\mathrm{n}$ junction in polycrystalline silicon can have well behaved characteristics. The major efficiency loss mechanism, introduced by the presence of grain boundries, apparently does not come from the lower value of shunt resistance but from the additional recombination loss along the grain boundaries. This paper's purpose is to review the status of MIS and SIS solar cell technologies and assess the potential of these structures to meet low cost goals.

Three major types of MIS/SIS solar cells are discussed in terms of structure, materials used in the fabrication, and the current collection under illumination. The types of solar cells discussed include the thin metal MIS structure, the conducting oxide SIS structure, and the MIS inversion layer device. The specific advantages of a MIS/SIS solar cell are investigated by the use of theoretical calculations. The spectral response, short circuit current, open circuit voltage, fill factor, and cell efficiency have been calculated for the MIS/SIS case, the advanced diffused, and standard diffused solar cells.

Several specific problem areas exist with these devices. The possible loss mechanisms in the MIS/SIS device are detailed, the cell stability and degradation mechanisms are identified, and the fabrication techniques amenable to large scale use are discussed. A major conclusion of the paper is that the MIS/SIS solar cells have no apparent advantage over diffused $p-n$ junctions. 
THIS PAGE

\section{WAS INTENTIONALLY LEFT BLANK}




\section{TABLE OF CONTENTS}

Page

$1.0 \quad$ Introduction $\ldots \ldots \ldots \ldots \ldots \ldots \ldots \ldots \ldots \ldots \ldots \ldots \ldots \ldots \ldots \ldots \ldots, 1$

$2.0 \quad$ MIS and SIS Solar Cell Structures $\ldots \ldots \ldots \ldots \ldots \ldots \ldots \ldots \ldots \ldots \ldots \ldots \ldots$

3.0 General Advantages of MIS and SIS type Solar Cells on

Polycrystalline Substrates .................................. 7

3.1 Calculation of the Short Circuit Current $\ldots \ldots \ldots \ldots \ldots \ldots \ldots \ldots \ldots, 8$

3.2 Calculation of the Open Circuit Voltage $\ldots \ldots \ldots \ldots \ldots \ldots \ldots \ldots \ldots, 11$

3.3 Calculation of the Fill-Factor $\ldots \ldots \ldots \ldots \ldots \ldots \ldots \ldots \ldots \ldots \ldots, 12$

3.4 Calculation of the Efficiency $\ldots \ldots \ldots \ldots \ldots \ldots \ldots \ldots \ldots \ldots \ldots \ldots, 12$

4.0 General Problem Areas with the MIS/SIS Structure................ 17

5.0 Relative Advantages and Disadvantages of the MIS/SIS

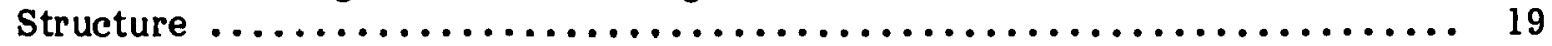

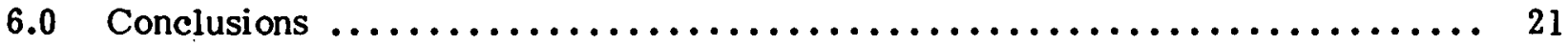

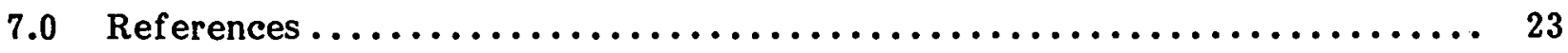




\section{THIS PAGE}

\section{WAS INTENTIONALLY \\ LEFT BLANK}




\section{LIST OF FIGURES}

$\underline{\text { Page }}$

2-1 Cross section of three MIS/SIS structures $\ldots \ldots \ldots \ldots \ldots \ldots \ldots \ldots \ldots \ldots \ldots \ldots$

3-1 Quantum yield of MIS, advanced and standard diffused cells, $25 \mu \mathrm{m}$ thick film no BSF ............................... 9

3-2 Short-circuit current as a function of grain size, $25 \mu \mathrm{m}$ thick

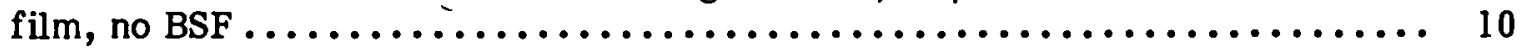

3-3 Open-circuit voltage as a function of grain size, $25 \mu \mathrm{m}$ thick film, no BSF

3-4 Fill-factor as a function of grain size $25 \mu \mathrm{m}$ thick film, no BSF.

3-5 Efficiency versus grain size, $25 \mu \mathrm{m}$ thick film with and without BSF

\section{LIST OF TABLES}

$\underline{\text { Page }}$

2-1 Current Status of MIS/SIS Technologies $\ldots \ldots \ldots \ldots \ldots \ldots \ldots \ldots \ldots \ldots \ldots \ldots$

3-1 Characteristics of the Three Types of Polycrystalline Silicon Solar Cells ...................................... 8

3-2 Definition of the Symbols $\ldots \ldots \ldots \ldots \ldots \ldots \ldots \ldots \ldots \ldots \ldots \ldots \ldots \ldots$ 


\section{SECTION 1.0}

\section{INTRODUCTION}

Metal-Insulator-Semiconductor (MIS) and Semiconductor-Insulator-Semiconductor (SIS) structured solar cells have been considered a viable alternative to thermally diffused $p-n$ junctions for use on polycrystalline thin-film silicon substrates. These beliefs are based on the fact that problems can arise during the junction formation by thermal diffusion on polycrystalline silicon. Also, the MIS and SIS type devices can possibly be manufactured in a less expensive way than diffused cells. Early work revealed that thermal diffusion of a junction in polycrystalline silicon substrates could impose severe problems. These problems are due to a possible enhanced diffusion along the grain boundaries introducing current leakage paths. These leakage currents result in low shunt resistance and a reduced value of the cell fill factor. However, several groups have reported diffused junction characteristics $[1,2,3]$ of cells on polycrystalline silicon substrates with good values of fill factor. These recent reports indicate that excessive values of leakage currents can be overcome. The major efficiency loss mechanism, introduced by the presence of grain boundaries, appears to come not from the lower values of shunt resistance but from the additional recombination loss along the grain boundaries $[4,5]$. The resultant effects are lower values of the short circuit current and, to a smaller extent, the open circuit voltage. Considering the problems of recombination loss at the grain boundaries, no direct major advantage of using an MIS or SIS structure seems to exist. Many of the fabrication techniques for these cells appear to be batch type vacuum processes that are less amenable to large scale production. An exception to the batch type fabrication processing is the recently developed spray deposition process of transparent oxide semiconductors [6].

This paper's purpose is to review the status of MIS and SIS solar cell technology and to assess the potential of these structures to meet low cost goals. Initially, the paper describes the commonly used MIS and SIS structures. The third section presents the general advantages of MIS and SIS structured solar cells in terms of use with polycrystalline silicon substrates with emphasis on the enhanced blue response of these cells. The general problem areas are described in the fourth section. The following section concerns a study of the relative advantages and disadvantages of the different MIS and SIS solar cell structures and summarizes the results achieved to date. The final section summarizes the paper and presents some conclusions. 


\section{SEPI}




\section{SECTION 2.0}

\section{MIS AND SIS SOLAR CELL STRUCTURES}

Three major MIS or SIS type solar cell structures have been proposed. In the first type shown in Figure 2-l(a), the collecting barrier is formed by a thin-metal/thin-oxide silicon structure. The thin metal layer is made semi-transparent to visible radiation by keeping its thickness around $50 \dot{\mathrm{A}}$. There exists an electrical resistivity/optical transmitivity tradeoff of the thin metal layer, and the thickness chosen is usually a compromise value. Problems with electrical sheet resistance could be overcome by adequate contact grid metalization, but this could add a significant price increase if photolithographic steps are needed for fine line geometries. The thin insulating oxide layer is typically between $15 \dot{A}$ and $30 \dot{A}$. This layer's purpose is to block the majority carrier currents injected into the metal at forward bias from the semiconductor while still being transparent to the photogenerated minority carrier current, and thereby increasing the open circuit voltage. The oxide layer also reduces the surface recombination velocity by several orders of magnitude. Once collected, the photogenerated carriers travel through the thin metal layer and along the silicon surface. The carriers can be collected by the thick metal grid pattern present on top of the thin metal layer. The thick metal grid is similar to those used on conventionally diffused junction cells. The collecting barrier is brought about by the difference in work function between the thin metal and the underlying silicon. The barrier height is also influenced by the properties of the thin oxide. The highest efficiencies (13.1\% active area, AM1) have been achieved with low-work function metals such as $\mathrm{Al}, \mathrm{Ti}$, or $\mathrm{Cr}$ on p-type silicon [7, 8, 9] (Table 2-1). In this case, the surface under the thin oxide layer is inverted, and an $\mathrm{n}^{+}$layer is induced into the silicon. These cells can be described as $n^{t} / \mathrm{p}$ cells. The thin oxide layer is transparent for the electron flow (minority carriers) in both directions, but it forms a barrier for the hole current flow.

In the SIS type cell shown in Figure 2-1(b), the collecting barrier is formed by the difference in work functions between the conductive semiconductor oxide and the silicon. Specific advantages of conductive, transparent semiconductor oxides, such as ITO, $\mathrm{SnO}_{2}$ or $\mathrm{Cd}_{2} \mathrm{SnO}_{4}$, include:

- Index of refraction matching to provide antireflection properties,

- minimal visible absorption in the oxide layer" due to the wide bandgap semiconductor, and

- oxide films which can be deposited as low temperatures so that interdiffusion can be minimized and an abrupt junction can be formed.

The conductive oxide provides a lateral current path along the surface that allows the minority carriers, generated in the bulk and collected by the surface barrier, to reach the contact grid. The thin insulating oxide introduces the same beneficial effects in the SIS device as the thin metal MIS type structure. The highest efficiencies with SIS type cells have been obtained with indium-tin-oxide (ITO) [10] on p-type silicon and with tin-oxide $\left(\mathrm{SnO}_{2}\right)$ on n-type silicon [6]. Cell efficiencies of $14.0 \%$ and $12.0 \%$, respectively, have been achieved with these cells (Table 2-1). One major problem with the conductive oxide ITO is that the work function can change as an unknown function during the fabrication process. Thesc changes in work function can affect the Fermi level position in the oxide, the degeneracy and resistivity of the oxide films, and hence, the final efficiency of the device. 


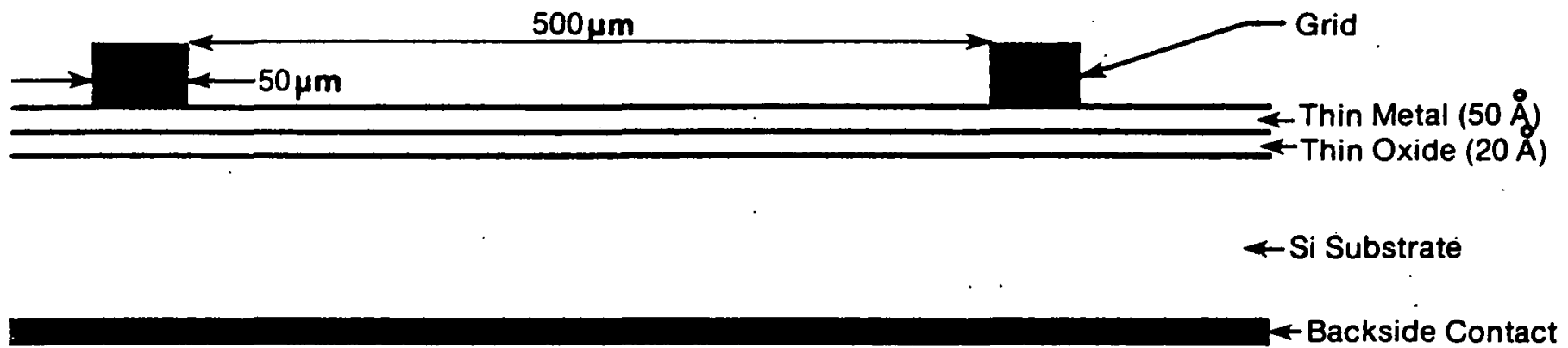

Figure 2-la. MIS with Transparent Metal Film

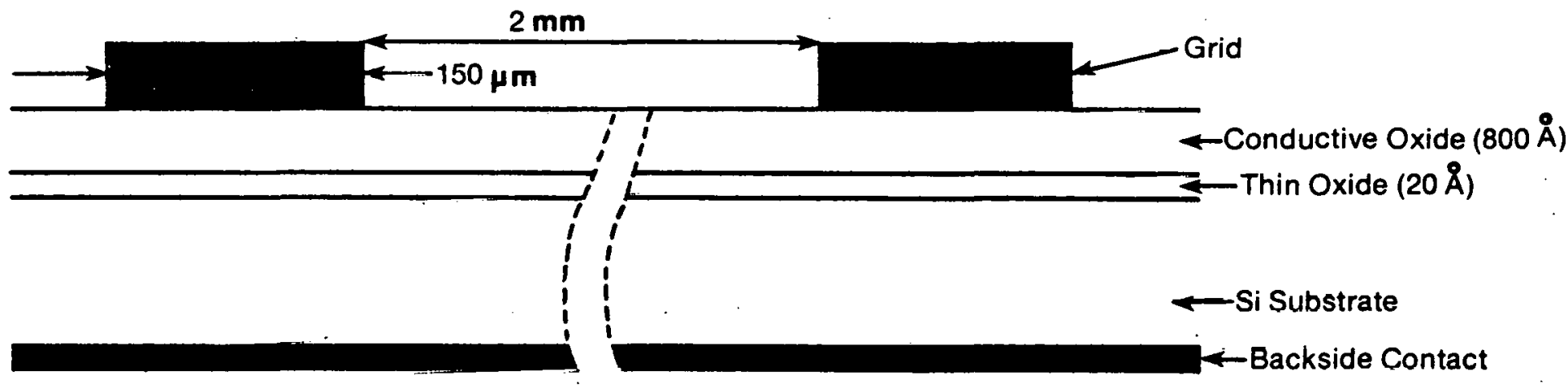

Figure 2-Ib. MIS with Conductive Oxides

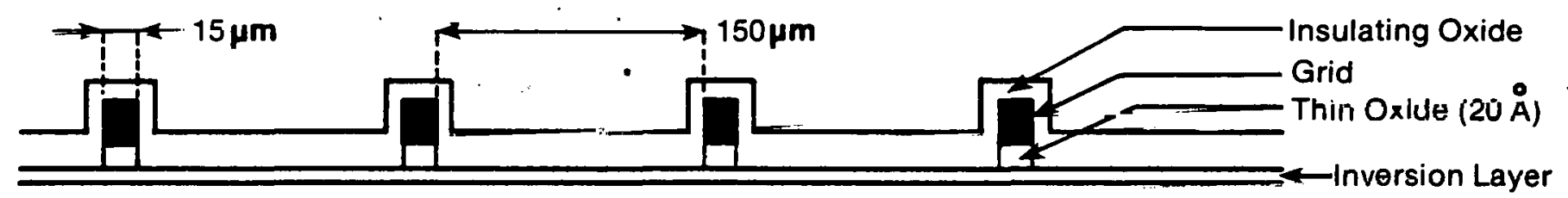

$\longleftarrow$ Si Substrate - backside Contract

Figure 2-1c. MIS Grating Inversion Layer Cell

Figure 2-1. Cross Section of the Three MIS/SIS Structures 
Table 2-1. CURRENT STATUS OF MIS/SIS TBCHNOLOGIES

\begin{tabular}{|c|c|c|c|c|c|c|c|c|c|c|c|}
\hline & & & Are日 & Voc & $\underset{\text { (ma }}{\mathrm{J}}$ & 2) & Fill Factor & . & & & \\
\hline & Technology & Material & $\left(\mathrm{cm}^{2}\right)$ & $(\mathrm{mV})$ & Active & Total & (Percent) & & Active & Total & Source \\
\hline \multirow[t]{4}{*}{ Thin Metal MIS } & Chromium & Single, $p$ & 2.0 & 570 & 34.0 & & 68 & & 13.1 & & 7 \\
\hline & Chromium & Wacker ${ }^{a}, p$ & 2.0 & 500 & 24.2 & & 73 & & 8.8 & & 7 \\
\hline & Titanium & Single, $p$ & 2.6 & 550 & \multicolumn{2}{|c|}{$33^{\mathrm{b}}$} & 65 & & \multicolumn{2}{|c|}{$11.8^{\mathrm{b}}$} & 8 \\
\hline & Aluminum & Single, $p$ & 1.5 & 515 & & 27.5 & 65 & & & 9.1 & 32 \\
\hline \multirow[t]{4}{*}{ SIS “ } & ITO, Ion Beam & Single, $p$ & 1.36 & 587 & & 32.5 & 74 & & & 14.0 & 10 \\
\hline & TTO, Ion Beam & W.acker, p & 2.6 & 542 & & 24.9 & 71 & : & & 9.5 & 10 \\
\hline & TTO, Ion Beam & Single, $p$ & 2.07 & 518 & 31.0 & & 72 & & 12.0 & & 33 \\
\hline & rTo, Ion Beam & Monsanto ${ }^{c}, p$ & 3.93 & 462 & 20.9 & & 68 & & 6.6 & & 33 \\
\hline \multirow{9}{*}{-} & $\mathrm{MoO}_{3}$, Ion Beam & Single, $p$ & 0.04 & 225 & 14.6 & & 53 & & 1.7 & & 34 \\
\hline & ГTO, Spray & Single, $n$ & 3.94 & 590 & & 28.3 & 66 & & & 11.1 & 35 \\
\hline & ITO, E-Beam & Single, $n$ & 4.0 & 485 & & 30.3 & 67 & & & 9.8 & 30 \\
\hline & $\mathrm{SnO}_{2}$, spray & Single, $n$ & 3.84 & 615 & $\cdot$ & 29.0 & 68 & & : & 12.1 & 6 \\
\hline & $\mathrm{SnO}_{2}$, spray & Wacker, $\mathbf{n}$ & 4.0 & 560 & & 26.6 & 68 & & & 10.1 & 6 \\
\hline & $\mathrm{SnO}_{2}$, E-Beam & Single, $n$ & 4.0 & 590 & & 29.0 & 65 & & & 11.1 & 18 \\
\hline & $\mathrm{Cd}_{2} \mathrm{SnO}_{4}$, Ion Beam & Single, p & - & 500 & 31.8 & & 53 & & 8.4 & & 10 \\
\hline & ITO, spray & Single, $n$ & 0.3 & 520 & 31.5 & & 70 & $=$ & 11.5 & . & 36 \\
\hline & ITO, spray & Wacker, $\mathrm{n}$ & 3.75 & 500 & & 29.0 & 71 & & & 10.3 & 37 \\
\hline \multirow[t]{2}{*}{ Grating MIS } & Aluminum, (SiO) & Single, $p$ & $\mathbf{3 . 0}$ & 642 & 35.6 & & 77 & & 17.6 & & 11 \\
\hline & Aluminum, (SiO) & Wacker & 3.1 & 558 & 30.8 & & 73 & & 12.5 & & 38 \\
\hline \multirow[t]{2}{*}{ Diffused Junction } & Phosphorous diff. & Semi Crys., $p$ & 4.0 & 600 & & 34.5 & 78 & & & 16.1 & 2 \\
\hline & Phosphorous diff. & Viacker, $p$ & 4.5 & 542 & $\cdot$ & 27.9 & 77 & & & 11.6 & 39 \\
\hline
\end{tabular}

a The "Wacker" material refers to polycrystalline casted material.

bThe $J_{s c}$ or efficiency column numbers present in the center indicate that an active or inactive area has not been defined.

The "Montanto" material refers to single pass float zone refined polycrystalline silicon.

$\mathrm{d}_{\text {Included for comparison purposes only. }}$ 
The operation of the grating MIS cells shown in Figure 2-1(c) relies on the induction of an inversion layer by the fixed charge present in the insulating oxide deposited onto the silicon. The insulating oxide serves as an anti-reflection coating on the silicon. The inversion layer acts as a collecting barrier for the photogenerated minority carriers, and the collected carriers travel through this layer. The MIS structure present under the grid acts as an ohmic contact to the inversion layer. Since the active part of MIS grating cells is not covered by metal layers, no transparent metal layers are required. The highest efficiencies obtained to date (17.6\% active area, AM1) with the MIS or SIS structured silicon solar cells have been reported for MIS grating cells [11] (Table 2-1). One explanation for these high efficiency values is that the inversion layer cell operates like an ideal $p-n$ junction device. The thin oxide layer is not nearly as critical in this type of device so long as it does not provide a tunnel barrier to photogenerated carriers. 


\section{SECTION 3.0}

\section{GENERAL ADVANTAGES OF MIS AND SIS TYPE SOLAR CELLS ON POLYCRYSTALLINE SUBSTRATES}

The original reasons why MIS/SIS type barriers on polycrystalline silicon were preferred over diffused junctions were the absence of leakage currents associated with enhanced grain boundary diffusion and the potentially less expensive fabrication processes. However, more detailed studies have proven these original reasons to appear somewhat invalid. Indeed, enhanced recombination of minority carriers, not the leakage and shunting problems, seem to be the major difficulty associated with grain boundaries in polycrystalline substrates. In addition, several of the MIS/SIS type cells involve costly batch type vacuum fabrication processes less amenable to large scale production and more expensive than diffusion technology. This, of course, is not true in the case of the high through-put, oxide semiconductor spray technologies.

Claims exist that MIS/SIS type cells could yield higher open circuit voltages than diffused cells [1 2] since, by proper choice of the metal work function, the dark forward current injected from the substrate in to the metal could be reduced or completely eliminated. The corresponding current in diffused cells, injected from the substra te into the diffused layer, limits the open circuit voltage in high quality single crystal cells [13]. On the other hand, since in polycrystalline films one deals with smaller diffusion lengths in the substrate, due to enhanced recombination in and near the grain boundaries, the open circuit voltage will mainly be limited by the current injected fromthe emitter into the substrate. Since this current is identical in a diffused or MIS/SIS cell, substantially higher Voc values for MIS/SIS type cells on polycrystalline films cannot be expected.

However, conventionally diffused cells still suffer from a disadvantage rela ted to the presence of a dead layer in the upper part of the diffused region [14]. This dead layer causes a fall-off of the quantum efficiency in the UV part of the solar spectrum. Since the transition from single to polycrystalline substrates mainly causes a loss of the quantum yield for longer wavelengths through a reduction of the diffusion length, it is clear that the enhancement of the blue response of a cell is relatively more important on poly than on single crystal silicon. Due to the absence of a dead layer in an MIS/SIS type cell, this type of cell inherently has an improved blue response. Therefore, it seems important to determine the potential inerease in the air mass one (AM1) efficicncy by going from a diffused cell to an MIS/SIS type using polycrystalline silicon substrates.

To make the necessary calculations to clarify this point, it was assumed that a $25 \mu \mathrm{m}$ thick polycrystalline silicon, p-type thin film was deposited onto a foreign substrate. A $25 \mu \mathrm{m}$ thick silicon film was chosen for these calculations due to the trade-off between optical integrity and material usage. All grain boundaries were assumed to be columnar or perpendicular to the substrate. The grain size was varied between $25 \mu \mathrm{m}$ and $6.4 \mu \mathrm{m}$. All short circuit currents, open circuit voltages, and fill factors have been calculated as a function of grain size for a standard diffused junction, an advanced diffused cell, and an MIS or SIS type cell. The major characteristics of the structures are listed in Table 3-1. 
Table 3-1. CHARACTERISTICS OF THE THREE TYPES OF POLYCRYSTALIITE SIIICON SOLAR CEIISS

\begin{tabular}{lccc}
\hline \multicolumn{1}{c}{ Charac teristics } & \multicolumn{2}{c}{ Types of Solar Cells } \\
\cline { 4 - 4 } \multicolumn{1}{c}{} & Standard Diffused & Advanced Diffused & MIS \\
\hline $\mathrm{N}_{\text {Afe Film) }}$ (Aceptor Concentration in & $10^{16}\left(\mathrm{~cm}^{-3}\right)$ & $10^{16}\left(\mathrm{~cm}^{-3}\right)$ & $10^{16}\left(\mathrm{~cm}^{-3}\right)$ \\
Junction depth & $0.3 \mu \mathrm{m}$ & $0.1 \mu \mathrm{m}$ & 0 \\
Dead laycr thickness & $0.125 \mu \mathrm{m}$ & $0.005 \mu \mathrm{m}$ & 0 \\
Dn (cm $\left.{ }^{2} / \mathrm{s}\right)$ & 25 & 25 & 25 \\
Depletion layer thickness & $0.3 \mu \mathrm{m}$ & $0.3 \mu \mathrm{m}$ & $0.3 \mu \mathrm{m}$ \\
\hline
\end{tabular}

\subsection{Calculation of the Short Circuit Current}

Following Lindmayer and Allison [14] the assumption has been that all carriers generated within the dead layer are lost, and those carriers generated in the diffused layer outside of the dead layer and in the depletion region are collected. Both cases of infinite and zero recombination velocity at the silicon film/substrate in terface have been assumed. The latter case refers to a cell with a backsurface field. To correlate diffusion length and lifetime with grain size, the empirical formula proposed by Ghosh [15] has been used:

$$
\tau=5 \times 10^{-6} \times \text { grain size in } \mathrm{cm} \quad \text { (seconds) }
$$

Although no strong theoretical background for this formula for large grain size inaterial is apparent, it fits the experimental data ressonahly woll for grain sizes in the runge $100 \mu \mathrm{m}$ to $10,000 \mu \mathrm{m}$.

Assuming zero reflection loss and zero absorption loss in the thin metal films or antireflection oxides, the quantum yield of the three structures can now be calculated as a function of grain size in a straight forward manner. The results of these calculations are presented in Figure 3-1. As expected, the three structures have identical red responses whereas significant differences exist in quantum yield in the shor $t$ wavelength regions.

The AMl short circuit current follows from the quantum yield and the solar energy spectral distribution. To take reflection losses into accoint, a constunt wavelength independent reflection loss of five percent has been assumed for all structures. This loss overestimates to some extent the advantage of blue enhanced cells. The calculated short circuit current density, per unit area of active surface area as a function of grain size, is given in Figure 3-2. Clearly a signifi cant improvement in the AMl short circuit current density can be expected by going from standard to very shallow diffusions. However, the difference in short circuit current between an advanced diffusion and an MIS/SIS cell seems marginally small. 


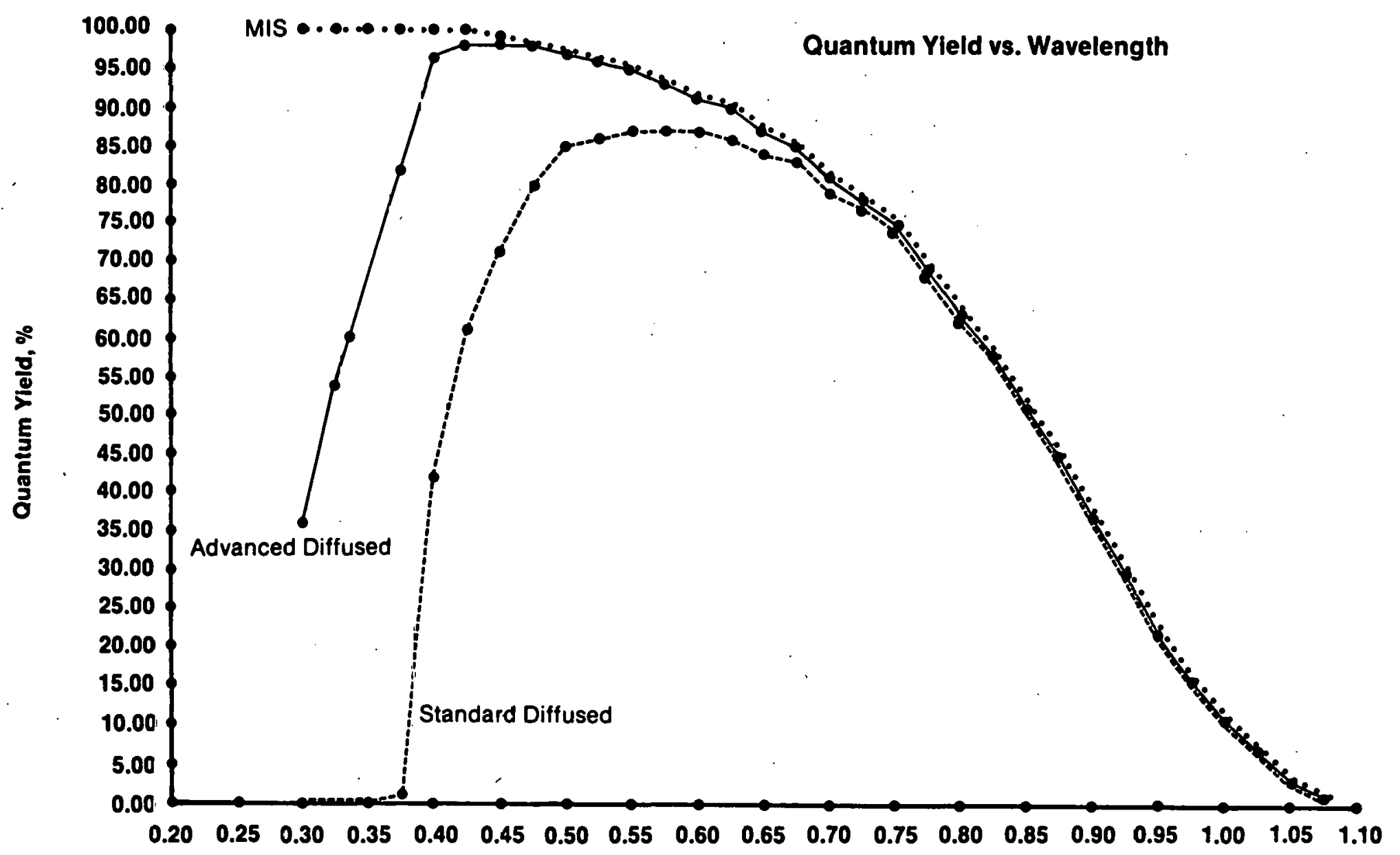

Wavelength, Microns

Figure 3-1. Quantum Yield of MIS, Advanced and Standard Diffused Cells, $25 \mu \mathrm{m}$ Thick Film, no BSF 


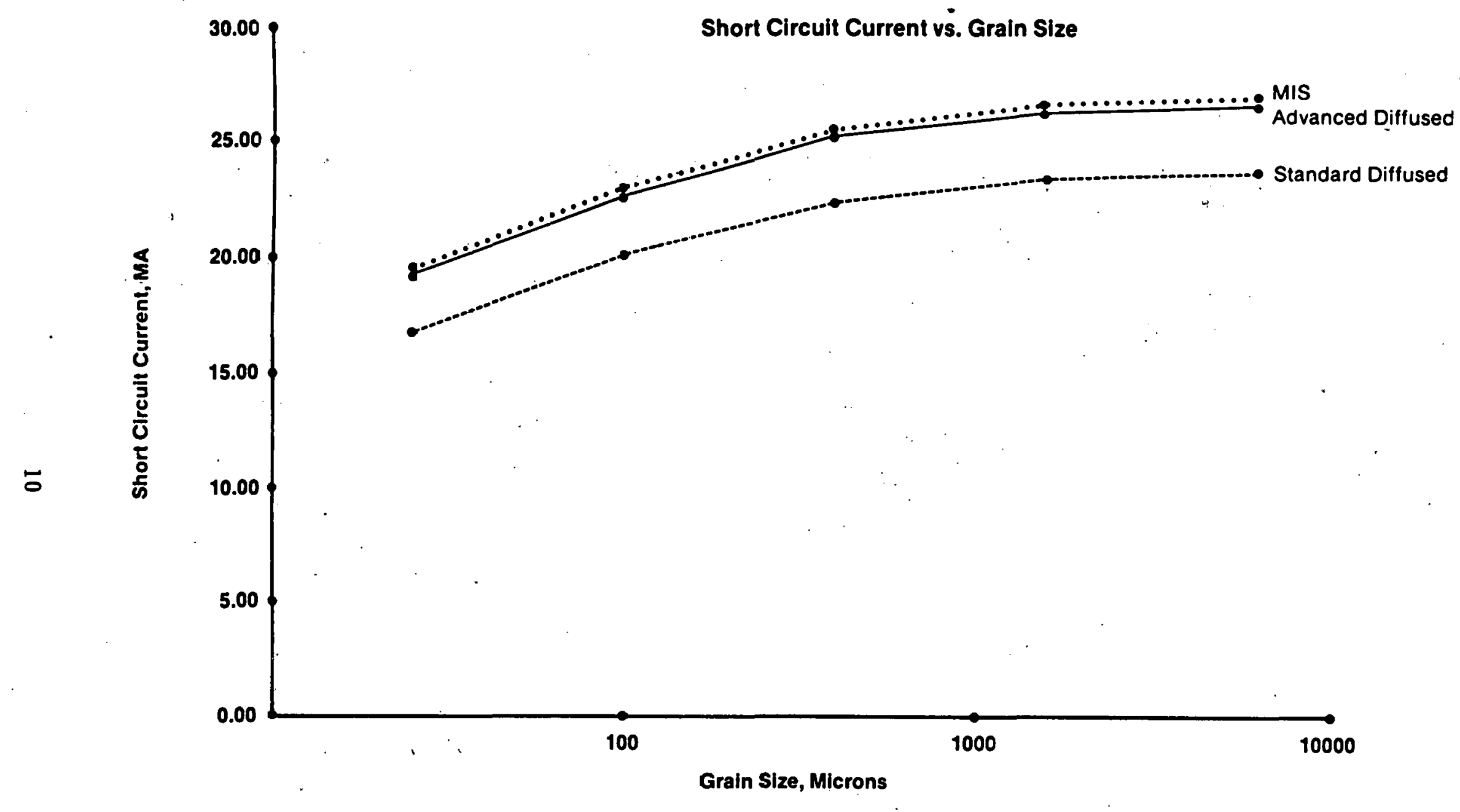

Figure 3-2. Short-Circuit Current as a Function of Grain Size, $25 \mu \mathrm{m}$ Thick Film, No BSF 


\subsection{Calculation of the Open Circuit Voltage}

Two components of the dark current have been considered: the recombination current in the space charge region and the diffusion-recombination current in the neutral base. For diffused cells, the current injected into the diffused layer has been disregarded. Also, for MIS/SIS type cells the current injected from the substrate into the metal or conduc tive oxide has not been considered. This assumption seems reasonable because of the smaller diffusion lengths in poly materials. The total dark current density then equals:

$$
J=J_{o(d i f)} \exp \frac{g V}{k T}+J_{o,(\text { rec })} \exp \frac{q V}{2 k T}
$$

where:

$$
\begin{aligned}
& J_{0,(\text { dif })}=\frac{q_{n} n_{i}^{2}}{L_{n}^{N}} \operatorname{coth}\left(H / L_{n}\right) \\
& J_{o,(\text { rec })}=\frac{q_{i} W}{2}
\end{aligned}
$$

for an infinite recombination, and

$$
J_{0,(\text { dif })}=\frac{q^{D} n_{i}^{2}}{L_{n}^{N}} \operatorname{coth}\left(H / L_{n}\right)
$$

\begin{tabular}{|c|c|c|}
\hline Symbol & Meaning & Units \\
\hline $\mathbf{q}$ & Elec tronic charge & coulomb \\
\hline $\mathrm{D}_{\mathrm{n}}$ & $\begin{array}{l}\text { Diffusion constant of electrons in } \\
\text { the base }\end{array}$ & $\mathrm{cm}^{2} /$ seconds \\
\hline $\mathbf{n}_{\mathbf{i}}$ & In trinsic concentration & $\mathrm{cm}^{-3}$ \\
\hline$L_{n}$ & $\begin{array}{l}\text { Diffusion length of electrons in } \\
\text { the base }\end{array}$ & $\mu \mathrm{m}$ \\
\hline $\mathbf{N}$ & Impurity concentration in the base & $\# / \mathrm{cm}^{3}$ \\
\hline $\mathbf{H}$ & Thickness of the silicon film & $\mu \mathrm{m}$ \\
\hline $\mathbf{W}$ & Depletion layer width & $\mu \mathrm{m}$ \\
\hline$\tau$ & Minority carrier lifetime & seconds \\
\hline $\mathrm{V}$ & Applied forward bias voltage & volts \\
\hline
\end{tabular}

for a zero recombination velocity at the film-substrate interface. The definition of the symbols is given in Table $3-2$.

Table 3-2. DEPINIFITION OF THE SYMBOLS 
By equating expression 2 to the value of short circuit current, the open circuit voltage $\left(V_{o c}\right)$ can be determined. Figure 3-3 shows $V_{o c}$ as a function of grain size for the standard diffused, advanced diffused and MIS/SIS type solar cells. The open circuit voltage of the advanced diffused cells tums out to be nearly identical to the values found for MIS/SIS type cells.

\subsection{Calculation of the Fill-Faetor}

The maximum power point for the different cells has been calculated using the values obtained from the $\mathrm{I}_{\mathrm{sc}}$ and using Eq. 2. To take series resistance in to account, the results were multiplied by a constant factor 8.93. According to the calculations of Hovel [16], a series resistance of $1 \mathrm{ohm}$ for a $1 \mathrm{~cm}^{2}$ silicon solar cell, drops the value of efficiency by $1 \%$ ( $15 \%$ to 14\%), which corresponds to a $7 \%$ reduction in cell output. Thus, for a well designed solar cell, losses of thls magnitude due to series resistance is a reasonable assumption. Results indicate only minor differences in fill factor exist for the three structures. This common value is given on Fig. 3-4.

\subsection{Calculation of the Efficiency}

AMl efficiencies have been obtained multiplying $I_{S c}, V_{o c}$, and the fill-factor. To compensa te for grid coverage, the active area ef ficiency has been multiplied with a constant factor 0.92 . This figure takes into account a typical $8 \%$ coverage to obtain the total area efficiency and is represented in Figure 3-5 as a function of grain size. Figure 3-5 clearly indicates the sizeable effect of the back-side recombination velocity on the efficiency of thin film $(25 \mu \mathrm{m})$ silicon cells as already determined by Hovel [16]. The calculations indicate that a back surface field type of structure is necessary to obtain $10 \%$ total area efficiency.

Due to the relatively larger importance of the blue part of the solar spectrum on polycrystalline films, blue enhanced cells yield considerably larger ef ficiencies than standard diffused cells. Standard diffused cells require four-times-larger grain sizes than blue enhanced cells to obtain $10 \%$ efficiency. To date, $9.7 \%$ efficient cells have been achieved on thin film $(25 \mu \mathrm{m})$ silicon by standard diffusion technology. The grain size in these cells was estimated to be $\approx 1-5 \mu \mathrm{m}$ [3]

Blue enhancement can be obtained by violet cell type diffusions or MIS/SIS type cells with metals or oxides as transparent as possible for the blue part of the spectrum. Since shallow diffusions are very critical on polycrystalline substrates, results may indicate that one of the MIS structures is more suitable to obtain blue enhancement on polycrystalline substrates. This increase supposes that the thin metals or oxides do not absorb the blue light present in the solar spectrum and, consequently, rules out the use of oxides such as SiO. For this latter oxide, the better intrinsic blue response of an MIS structure is largely lost because of the rather strong blue absorption. The better response assumes that the loss mechanisms described in the next section will be solved.

In addition to the better blue response, MIS/SIS type cells offer the advantage of a low temperature fabrication process. This process could be very advantageous if some grain boundary passivation technique is used prior to the cell fabrication. For a diffused cell made on such material the passivation effect could be lost during the high tempera ture step associated with the diffusion. On the other hand, diffused cells are compatible with passivation techniques implemented as the last step of the process. 


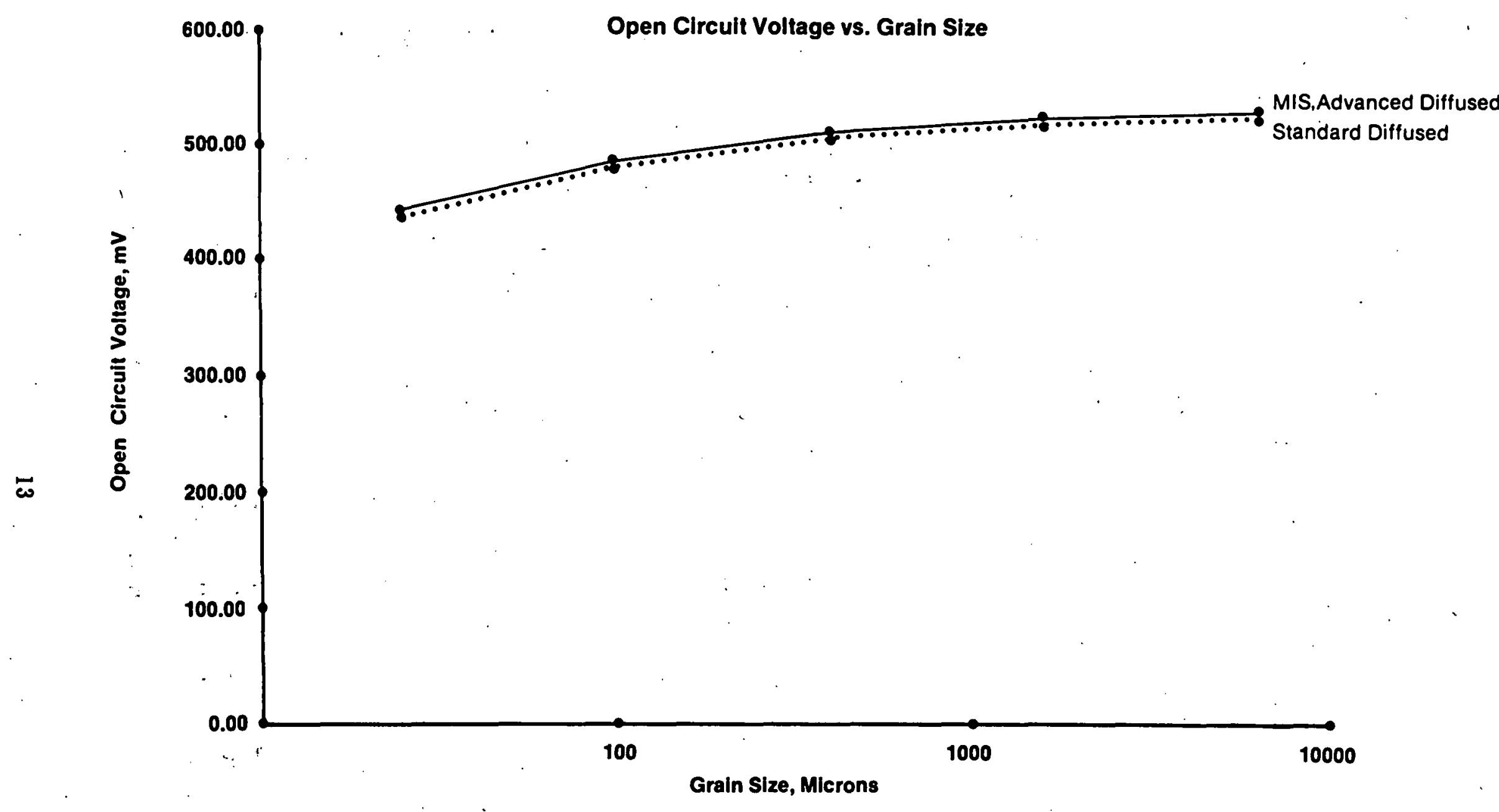

Figure 3-3. Open-Circult Voltage as a Function of Grain Size, $25 \mu \mathrm{m}$ Thick Film, No BSF 
Fill Factor vs. Grain Size

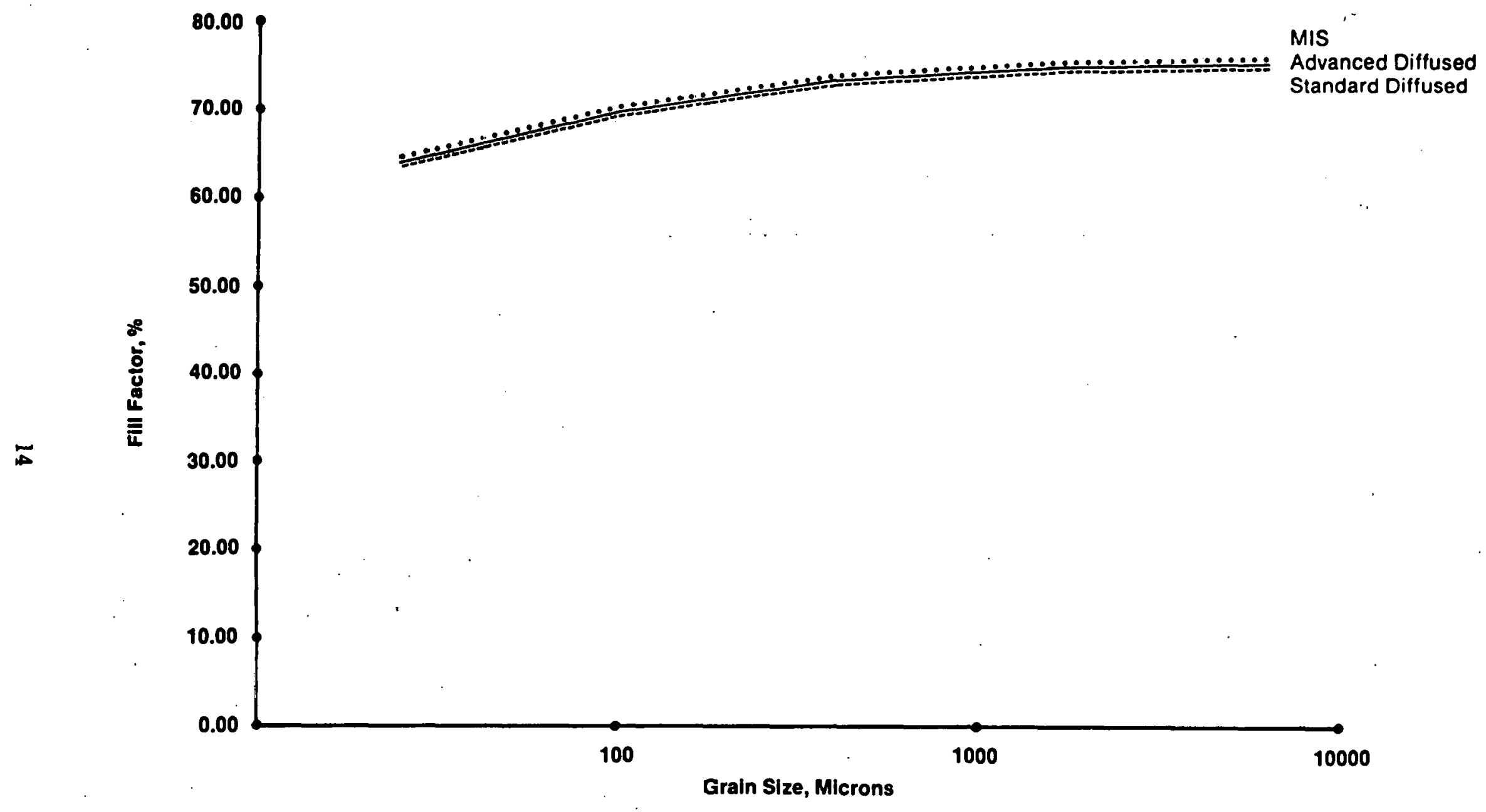

Figure 3-4. Fill-Factor as a Function of Grain Size $25 \mu \mathrm{m}$ Thick Film, No BSF 


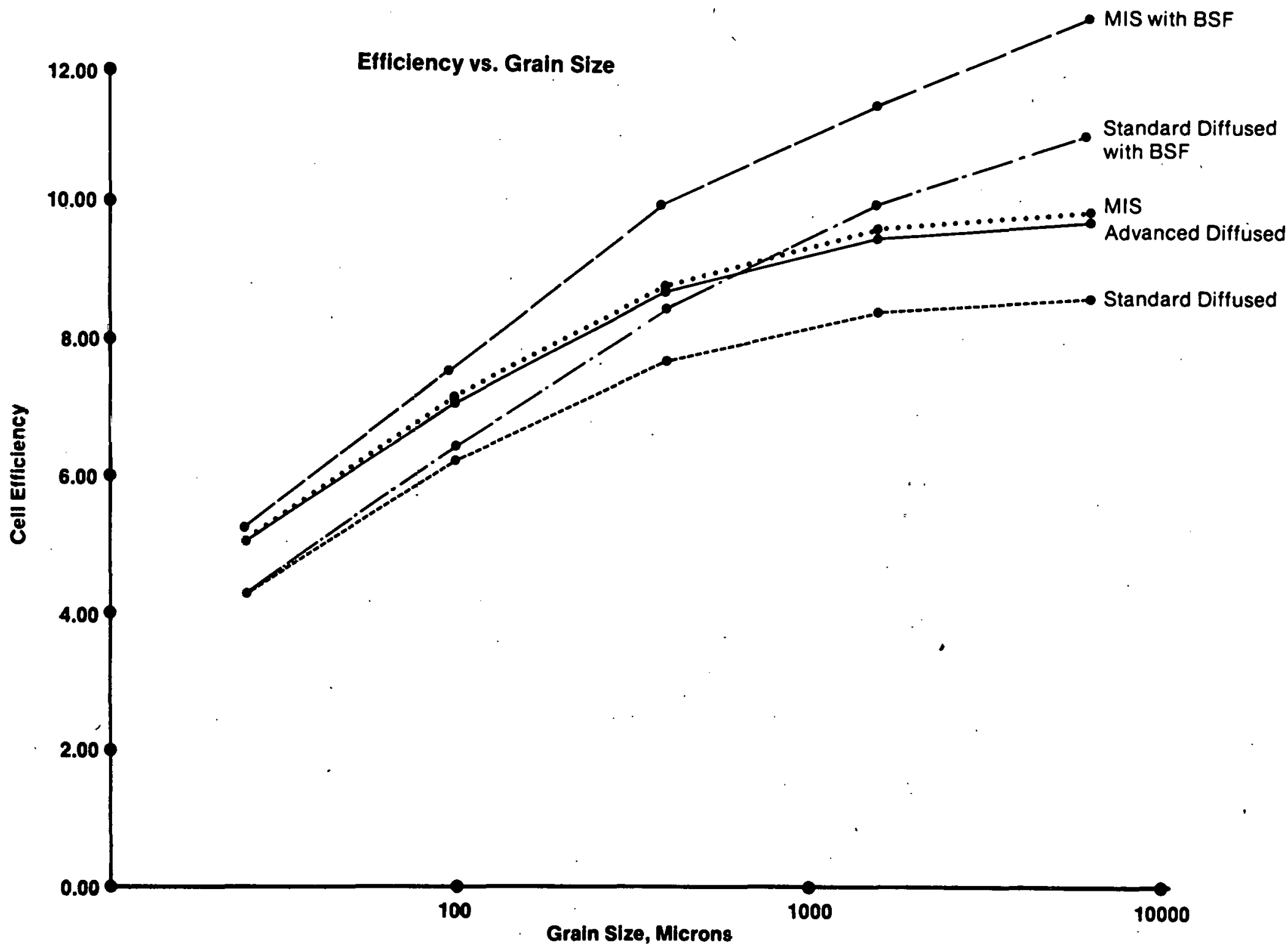

Figure 3-5. Efficiency vs. Grain Size, $25 \mu \mathrm{m}$ Thick Film, With and Without BSF 


\section{SERI*}




\section{SBCTION 4.0}

\section{GENERAL PROBLEM AREAS WTTH THE MIS/SIS STRUCTURE}

Several areas exist that raise questions on the potential feasibility of the MIS/SIS type device for large scale terrestrial applications. In general, experimental MIS/SIS cell efficiencies have been below values obtained by theoretical analysis as done in the previous section, and below those achieved with the diffused junction technology. Speculation is possible on the reasons for this inconsistancy. Loss mechanisms in the MIS/SIS type device that could account for the lower values of efficiency include:

- the relative immaturity of the MIS/SIS solar cell technology in regards to the advanced state of the thermal diffusion processes;

- transmission-reflection-absorṕtion of visible light associated with the thin metal or conducting oxide layer;

- incomplete coverage of a polycrystalline silicon surface by the thin metals due to grain boundary misorientations otherwise known as "step coverage;"

- work function variations in the deposited oxide semiconductors as a result of different fabrication techniques and parameters;

- difficulty in obtaining precise control over the thin insulating interfacial layer; and

- changes in the Fermi level position in oxide semiconductors or in the insulating oxide charge storage which affect the degree of silicon inversion.

Many of these problem areas have yet to be addressed in the research of the MIS/SIS type devices. Thus, the technology is far behind that of thermal diffusion.

Another questionable area is that of these cells'long-term stabilty. Many researchers report rapid degradation under stress conditions of light, bias, and temperature [17-20] . Several degradation mechanisms exist for these cells, but the most important seems to be oxygen diffusion through the thin metal or conducting oxide and the subsequent growth of the thin interfacial layer [21]. This mechanism has. been determined by elevated temperature tests inside and outside high vacuum chambers. Also, instability caused by humidity trapped in the thin oxide before metal deposition has been reported [22], but this type of instability can be avoided by using a dry oxygen process. Another possible degradation mechanism for the oxide semiconductor cells is a slowly varying configuration of the oxide semiconductor [18]. This mechanism could alter the electrical and optical properties of these thin films. The data on the degradation mechanisms in these cells is incomplete, and no condusive statement on cell stability can be made at this time.

In the present research of MIS/SIS devices, most techniques use some type of batchvacuum process that can be less amenable to large scale production. Vacuum steps in the cell fabrication processes are costly and somewhat energy intensive. However, the possibility of using continuous flow processes must not be excluded as indicated by the use of spray techniques [6]. The MIS/SIS system, unlike the diffused junction, is critically sensitive to interfacial state densities [23]. This problem is critical because, like the interfacial layer itself, it is very difficult to control. Recent research concluded that surface state densities can be changed by surface etching, surface preparation, and the 
type of silicon used [24]. Also, the density of surface states could be affected by fabrication procedures such as direct ion-beam milling of the silicon surface [25].

The MIS grating solar cell requires fine line geometry. These geometries are usually achieved by photolithographic techniques. Photolithographic steps in a large scale production situation possibly may not meet low cost goals. On the other hand, the possibility should not be excluded that the fixed charge in the oxides could be enhanced by chemical treatment. Thus, the finger spacing could be wider, and other metallization techniques could be utilized.

The final general problem area to be addressed is that of cell yield or fabrication repeatability. Unlike the methods of thermal diffusion where most wafers per batch are identical, most MIS/SIS fabrication techniques have shown wide variation in solar cell parameters from run to run. This is often true even when identical fabrlcation parameters are used. These problems must be solved before MIS/SIS cells can be produced in reasonable quantities. 


\section{SECTION 5.0}

\section{RELATTVE ADVANTAGES AND DISADVANTAGES OF THE MIS/SIS STRUCTURE}

This section compares the relative merits of each structure; thin metal MIS, conducting oxide SIS, and grating MIS, and summarizes the results achieved to date.

A strong trade off exists with thin metal MIS cells between sheet resistance and optical transmission. Obviously, the thicker the metal, the lower the electrical sheet resistance, but there is a subsequent reduction in optical transmission. This trade-off suggests a metal thickness to obtain optimum performance. In the transparent conductive oxide SIS cells, this problem is reduced considerably. Because the optical properties of the oxide films are relative independant of film thickness, the electrical sheet resistance can be minimized by depositing a thick film. Although thick oxide films can solve some problems, the thicker film may need an additional anti-reflection coating to achieve lower reflection losses [26]. The MIS grating cell appears to be best considering these parameters. Because of the nature of the thick contact grid pattern, there is no optical transmission/sheet resistance trade off. Of course, with this cell structure, additional photolithographic steps may be necessary.

Variations in the work function of metals and oxide semiconductors can have deleterious effects on the cell performance. In the thin metal MIS-type device, the work function can fluctuate up to $\approx 1 \mathrm{eV}$ depending upon the thickness and evaporation rate of the film [27]. Similar problems exist in the fabrication of oxide semiconductors. In the case of ITO, several methods for deposition; i.e., ion-beam sputtering [28], de and rf sputtering [29], electron-beam deposition [30], and spray technology [6] have all been utilized in the fabrication of solar cells. Efficient solar cells have been fabricated by several methods on both $\mathrm{n}$ - and p-type silicon. These results indicate that the ITO work function is strongly dependant upon the fabrication technique and the parameters used during the reactive sputtering. In some preliminary measurements on the photoemission spectra of $\mathrm{SnO}_{2}$ deposited on silicon, the emission spectra has been shown to change by up to $\approx 0.5$ $\mathrm{eV}$ depending on the deposition and surface preparation techniques [31]. Finally, in the MIS grating type solar cell, the metal grid pattern is usually thick enough to have properties of the particular bulk metal. Aspect ratios of four to one can easily be achieved. As a result, there is no work function variation of the metal.

Results by many research groups are summarized in the Table 2-1. The initial results indicate that the highest AMl Voc to date in silicon $(655 \mathrm{mV})$ has been achieved with an MIS grating device [11]. One notices that the thin metal MIS has $\mathrm{J}_{\mathrm{sc}}$ limitations, probably due to reduced optical transmission. Also, the drop in efficiency from MIS/SIS single crystal to polycrystalline is larger than expected. Finally, of all the MIS/SIS results presented (which represent the best to date), the cell efficiencies are not really any better and are actually slightly worse than those of the diffused junctions. Theoretically, cell efficiencies of the MIS/SIS structure should be better than those of the diffused junction tcchnology, but the results to date have been rather disappointing. 


\section{SE키}




\section{SECTION 6.0}

\section{CONCLUSIONS}

The principle advantages of the MIS/SIS technology are a potentially better blue response than diffused cells and a low temperature fabrication process. Blue enhancement obtained in diffused cells by using very shallow junctions probably will cause some severe problems if polycrystalline materials are used. Therefore, an MIS/SIS type cell might be an economical alternative to obtain a high short wavelength response.

The advantage of a low temperature process is apparent when polysilicon materials are used which have been grain boundary passivated prior to cell fabrication. Such materials would probably exclude any high temperature cell fabrication process. This advantage is irrelevant if the passivation is done af ter junction fabrication.

Literature of ten claims that MIS/SIS solar cells are simpler to make than diffused cells. A detailed look at these fabrication techniques reveals that, in general, they are more complex than those of the pn junction technology. Thus, conversion to MIS/SIS is not cost effective unless a non-vacuum process is utilized.

Apparently, MIS/SIS technologies will be economically competitive only if their efficiencies in a production environment are higher than those of diffused cells. Although the theoretical efficiency of MIS/SIS cells is somewhat higher than diffused cell efficiencies, the values actually measured in practice are considerably lower. Therefore, the achievement of repeatable high efficiencies remains a prime objective. Other important specific studies include degradation mechanisms, interfacial oxide properties and formation, work function measurements, conductive oxide reaction mechanisms, and an analysis of fabrication techniques amenable to large scale product. These types of studies are necessary before highly efficiencient MIS/SIS devices can consistently be obtained. 


\section{SE₹I萧}




\section{SECTION 7.0}

\section{REFERENCES}

1. Fisher, H.; Pschunder, W. "Low Cost Solar Cells Based on Large-Area Unconventional Silicon." IEEE Transactions on Electron Devices. vol. ED-24 (no. 4): p. $438-441$; 1977.

2. Lindmayer, J. "Characteristies of Semicrystalline Silicon Solar Cells." 13th Photovoltaic Specialists Conference; Washington, DC; 1978. pp. 1096-1100.

3. Chu, T. L.; Chu, S. S.; Lin, C. L.; Abderrassoul, R. "Silicon Solar Cells on Unidirectionally Recrystallized Metallurgical Silicon." IEEE Transactions on Electron Devices. vol. ED-24 (no. 4): pp. 442-446; 1977.

4. Lanza, C.; Hovel, .H. J. "Efficiency Calculations for Thin-Film Polycrystalline Semiconductor Schottky Barrier Solar Cells." IEEE Transactions on Electron Devices. vol. ED-24 (no. 4): pp. 392-396; 1977.

5. Card, H. C.; Yang, E. S. "Electronic Processes at Grain Boundaries in Polycrystalline Semiconductors Under Optical Illumination." IEEE Transactions on Electron Devices. vol. ED-24 (no. 4): pp. 397-40 1; 1977.

6. Feng, T.; Ghosh, A. K.; Fishman, C. "Spray Deposited High Efficiency $\mathrm{SnO}_{2}$ Silicon Solar Cells." Applied Physics Letters. vol. 35 (no. 3): pp. 266-268; 1979.

7. Rajkanan, K.; Anderson, W. A.; Rajeswaren, G. "Loss Mechanisms Analysis in Single and Poly-S: MIS S: Solar Cells to Produce a 13.2\% Efficiency." IEEE Electron Device Meeting; December 1979; Washington, DC.

8. Fabre, E. "MIS Silicon .Solar Cells." Applied Physics Letters. vol. 29 (no. 9): pp. 607-610; 1976.

9. Charlson, E. J.; Lien, J. C. "An Aluminum p-Silicon MOS Photovoltaic Cell." Journal of Applied Physics. vol. 46 (no. 9): pp. 3221-3229; 1975.

10. Shewchun, J. Annual Progress Report submitted to Solar Energy Research Institute under Contract No. XS-9-8233-1.

11. Godfrey, R. B.; Green, M. A. "A 655 mV Open-Circuit Voltage, 17.6\% Efficient Silicon MIS Solar Cell." Applied Physies Letters. vol. 34 (no. 11): pp. 790-793; 1979.

12. Pulfrey, D. L. "MIS Solar Cells: A Review." IEEE Transactions on Electron Devices, vol. ED-25 (no. 11): pp. 1308-1317; 1978.

13. Lindholm, F. A.; Neugroschel, A.; Sah, C. T.; Godlewski, M. P.; Brandhorst, H. W. "A Methodology for Experimentally Based Determination of Gap Shrinkage and Effective Lif etimes in the Emitter and Base of p-n Junction Solar Cells." 12th IEEE Photovoltaic Specialists Conference; Baton Rouge, LA; pp. 1-7; $19 \mathbf{9 7 6 .}$

14. Lindmayer, J; Allison, J. F. "The Violet Cell: An Improved Silicon Solar Cell." COMSAT Technical Review. vol. 3: pp. 1-22; 1973.

15. Ghosh, A. K.; Fishman, C.; Feng, T. "Theory of the Electrical and Photovoltaic Properties of Polycrystalline Silicon." Journal of Applied Physics. Accepted for publication, 1979. 
16. Hovel, H. J. Semiconductors and Semimetals, Vol. 11. New York: Academic Press; 1975; p. 86, p.100.

17. Goodnick, S. M.; Wager, J. F.; Wilmsen, C. W. "Thermal Degradation of ITO/pSilicon Solar Cells." Journal of Applied Physics. Accepted for publication, 1979.

18. Fishman, C.; Ghosh, A. K.; Feng, T. "Stability of SnO/n-Si Solar Cells." Solar Energy Materials, Vol. 1. pp. 181-185; 1979.

19. Nash, T. R.; Anderson, R. L. "Accelerated Life Tests of $\mathrm{SnO}_{2}-\mathrm{Si}$ Heterojunction Solar Cells." IEEE Transactions on Electron Devices. vol. ED-24: pp. 468-472; 1977.

20. Franz, S. L.; Andren, M. K.; Anderson, R. L. Stability of Conducting Oxide/Si Heterostructure Solar Cells. NBS Special Publication N0. 400-58; 1979; pp. 57-62.

21. Ponpon, J. P.; Siffert, P. "Formation and Stability of MS or MIS Schottky Solar Cells." 13th Photovoltaic Specialists Conference; Washington, DC. 1978; pp. 639-644 .

22. Townsend, W. G.; Lillington, D. R. "Progress on Aluminium p-type Silicon Schottky Barrier Solar Cells." lst European Photovoltaic Solar Energy Conference; Luxembourgh, Belgium. 1977; pp. 207-213.

23. Kar, S. "On the Role of Interface States in MOS Solar Cells." Journal of Applied Physics. vol. 49 (no. 10): pp. 5278-5283; 1978.

24. Kar, S; Dahlke, W. E. "Interface States in MOS Structures with 20-40 A Thick $\mathrm{SiO}_{2}$ Films on Nondegerate Si." Solid State Electronics. vol. 15: pp. 221-237; 1972.

25. Kar, S.; Gobis, L.; DuBow, J. "Electrical Characterization of Indium Tin Oxide on Silicon Solar Cells." Solid State Electronics. Accepted for publication, 1980.

26. Cheek, G.; Genis, A.; DuBow, J.; Pai Verneker, V. K. "Antireflection Properties of Indium Tin Oxide (ITO) on Silicon for Photovoltaic Applications." Applied Physics Letters. vol. 35 (no. 7): pp. 495-497; 1979.

27. Grove, A. S. Physics and Technology of Semiconductor Devices. New York: John Wiley and Sons, Inc; 1967; p. 346.

28. Cheek, G.; Inoue, N.; Goodnick, S.; Genis, A.; Wilmsen, C.; DuBow, J. "Fabrication and Characterization of Indium Tin Oxide (ITO)/Polycrystalline Silicon Solar Cells." Applied Physies Letters. vol. 33 (no. 7): pi. 643-645; 1978.

29. Thompson, W. G.; Anderson, R. L. "Electrical and Photovoltaic Characteristics of Indium-Tin Oxide/Silicon Heterojunctions." Solid State Electronics. vol. 21: Pp. 603-608; 1978.

30. Feng, 'I'.; Ghosh, A. K.; Flshman, C. "Efficient Electron Bcnm-Deposited ITO/n-Si Solar Cells." Journal of Applied Physics. vol. 50. (no. 7): pp. 4972-4974; 1979.

31. Feng, T.; Fishman, C.; Ghosh, A. K. "Barrier Heights and Interfacial Effects in $\mathrm{SnO}_{2} / \mathrm{Si}$ Solar Cells." IEEE 13th Photovoltaic Specialist Conference; Washington, DC. 1878; pp. 519-521.

32. Olson, L., Joint Center for Graduate Study, Richland, WA. (Unpublished work.) Solar Energy Research Institute; Polysilicon Review Meeting; June 1979.

33. DuBow, J., Colorado State University, Fort Collins, CO. (Unpublished work.) Verbal communication; November 1979. 
34. Osterwald, C.; Cheek, G.; DuBow, J. B.; Pai Verneker, V. K. "Molybdenum Trioxide $\left(\mathrm{MoO}_{3}\right)$ /Silicon Photodiodes." Applied Physics Letters. vol. 35 (no. 10): pp. 775-776; 1979.

35. Ghosh, A. K., Exxon Research Company, Linden, NJ. (Unpublished work.) Verbal communication; October 1979.

36. Ashok, S.; Sharma, P. P.; Fonash, S. J. "Spray-Deposited ITO/Silicon SIS Heterojunction Solar Cells." IEEE Transactions on Electron Devices, Special Issue on Photovoltaics. April, 1980.

37. Ghosh, A. K., Exxon Research Company, Linden, NJ. (Unpublished work.) Verbal communication; November 1979.

38. Godfrey, R. B.; Green, M. A. "A 15\% Efficient Silicon MIS Solar Cell." Applied Physics Letters: vol. 33 (no. 10): pp. 637-639; 1978.

39. Faughnan, B., RCA Laboratories, Princeton, NJ. (Unpublished work.) Verbal communication; October 1979. 


\begin{tabular}{|c|c|c|c|}
\hline $\begin{array}{c}\text { Document Control } \\
\text { Page }\end{array}$ & $\begin{array}{r}\text { 1. SERI Report No. } \\
\text { TR-311-493 }\end{array}$ & 2. NTIS Accession No. & 3. Recipient's Accession No. \\
\hline \multirow{2}{*}{\multicolumn{3}{|c|}{$\begin{array}{l}\text { 4. Title and Subtitle } \\
\text { MIS and SIS Solar Cells on Polycrystalline Silicon }\end{array}$}} & $\begin{array}{l}\text { 5. Publication Date } \\
\text { February } 1980 \\
\end{array}$ \\
\hline & & & 6. \\
\hline 7. Author(s) & Mertens & & 8. Periorming Organization Rept. No. \\
\hline 9. Pertorming Organizatic & Name and Address & & $\begin{array}{l}\text { 10. Project/Task/Work Unit No. } \\
3821.02\end{array}$ \\
\hline \multicolumn{3}{|c|}{$\begin{array}{l}\text { Solar Energy Research Institute } \\
1617 \text { Cole Blvd } \\
\text { Golden, Colorado } 80401\end{array}$} & $\begin{array}{l}\text { 11. Contract }(C) \text { or Grant (G) No. } \\
\text { (C) } \\
\text { (G) }\end{array}$ \\
\hline \multirow{2}{*}{\multicolumn{3}{|c|}{$\begin{array}{l}\text { Solar Energy Research Institute } \\
1617 \text { Cole Blvd } \\
\text { Golden Colorado } 80401\end{array}$}} & $\begin{array}{l}\text { 13. Type of Report \& Period Covered } \\
\text { Technical Report }\end{array}$ \\
\hline & & & 14. \\
\hline
\end{tabular}

15. Supplementary Notes

16. Abstract (Limit: 200 words)

MIS and SIS structured solar cells are receiving much attention in the photovoltaic community. Seemingly, these cells could be a viable alternative to thermally diffused $p-n$ junctions for use on thin-film polycrystaliine silicon substrates. This review describes MIS/SIS structured solar ce11s and the possible advantages of these structures for use with thin-film polycrystalline silicon. The results of efficiency calculations are presented. Also addressed are lifetime stablility and fabrication techniques amenable to large scale production. Finally, the relative advantages and disadvaltages of these cello and the results obtained are presented.

17. Document Analysis

a.Descriptors Silicon Solar Celis; Polycrystals; S1llcun; Thili Films; Substratcs; Efficiency; Fabrication; Comparative Evaluations; Spectrum Analysis

b. Identifiers/Open-Ended Terms MIS; SIS

c. UC Categaries

63

18. Availability Stätement

National Technical Information Service U. S. Department of Commerce 5285 Port Royal Road Springfield Virginia 22161

\begin{tabular}{|l|}
\hline $\begin{array}{l}\text { 19. No. of Pages } \\
31\end{array}$ \\
\hline $\begin{array}{r}\$ 4.50 \\
\end{array}$ \\
\hline
\end{tabular}

Q U.S. GOVERNMENT PRINTING OFFICE, 1080-677.178/60 